\title{
QUALITY OF BUFFALOE'S MEAT INFESTED WITH SARCOCYSTIS
}

\author{
N.Y. Mostafa and S.A. Yasein" \\ Fac. Vet. Med. Kafrelsheikh Univ. \\ "Parasitology Dept., Animal Health Inst.
}

\begin{abstract}
Although buffaloes meat is one of the most important sources of animal protein for a wide range of consumers, unfortunately there is a wide spread of Sarcocysts in their meat, such infestation often results in much economic losses in addition to it is possible zoonosis to human. The study planned to investigate the possible additional harmful effect of such parasite on meat quality. The obtained result revealed a noticeable increase in the total aerobic count, total enterobacteriaceae count, moisture percent, ash percent and $\mathrm{pH}$ value of the infested samples which were $2.21 \times 10^{6}, 2.50 \times 10^{5}, 81.62 \%$, $1.53 \%$ and 5.9, respectively, while that of normal samples were 7.41 $x 10^{5}, 1.15 \times 10^{5}, 77.91 \%, 1.17 \%$ and 5.31 , respectively at the same time the infested samples showed a significant decreases in the protein and fat percents which were $16.22 \%$ and $1.5 \%$ instead of $17.97 \%$ and $2.33 \%$ in non infested samples. The results also revealed that the parasitism has no significant effect on the number of Staphylococcus aureus or total mould and yeast between infested and non infested samples such serious changes greatly lower the meat quality, lowering its grade and may render it completely unacceptable
\end{abstract}




\section{INTRODUCTION}

One of the most serious problems among animals is the parasitic infestation which not affect the general health condition of animals only but also can cause certain diseases in human. Sarcocysts infestation is common in buffaloes worldwide as nearly all adult buffaloes are infested with some Sarcocysts species in certain countries as India (Dubey et al., 1989).

It is known that people can serve as final host for species of Sarcosporidia whose intermediate host is cattle (Sarcocysts hominis (Railliet and Lucet, 1981) or Sarcocystis bovinominis (Hydorn et al., 1975).

Man also is an intermediate host of some unknown sarcocystic species (Beaver et al., 1979). Volunteer infestation in man have shown that Sarcocystis hominis is only mild pathogenic in humans, causing nausea, stomach pain, and diarrhea. (Dubey et al., 1989).

AS regulations decide, carcasses that heavily infested with Sarcocysts were totally rejected, but that of light infestation, can pass for human consumption after partial trimming without restriction.

The question is the meat pass for human consumption after partial trimming of the parts contain the sarscocysts have the same quality of meat obtained from healthy non infested animals?

This is the aim of this work to compare the quality of meat from infested animals with meat of non infested ones as following. 


\section{Microbiological examination:}

a. Total aerobic bacterial count.

b. Total enterobacteriaceae count.

c. Staphylococcus aureus count.

d. Total yeast and mould count.

\section{Chemical examination:}

a. Chemical composition of meat by determination of, protein, fat, ash and moisture percentage.

b. Determination of $\mathrm{pH}$.

\section{MATERIALS AND METHODS}

\section{Collection of samples:}

A total of 70 random samples of freshly slaughtered buffaloes meat (40 meat samples infested with Sarcocysts, 30 of non infested meat samples) were collected from different abattoirs of El-Gharbia, Kafrelsheikh Governorate. The infested samples were identified according to (Soulsby, 1986).

The samples were transferred to laboratory under a septic condition with minimum time of delay in an ice box to be examined microbiologically, and chemically.

\section{Microbiological examination:}

a. Preparation of samples (APHA, 1992).

b. Determination of total aerobic bacterial count (APHA, 1992).

c. Determination of total enterobactericeae count (ICMSF, 1978). 
d. Determination of Staphylococcus aureus count (APHA, 1985).

e. Determination of yeast and mould count (APHA, 1985).

\section{Chemical examination:}

- Determination of pH (Pearson, 1884).

- Chemical composition of meat.

I. Determination of protein percentage $(A O A C, 1980)$.

II. Determination of fat percentage $(A O A C, 1980)$.

III. Determination of ash percentage (AOAC, 1980).

IV. Determination of moisture percentage (FAO, 1986).

\section{RESULTS}

Table (1): Statistical analytical results of total aerobic bacterial count (cfu/g) of examined meat samples.

\begin{tabular}{|c||c||c|c||c|c|c||}
\hline \multirow{2}{*}{ Samples } & \multirow{2}{*}{$\begin{array}{c}\text { No. of examined } \\
\text { samples }\end{array}$} & \multicolumn{2}{|c|}{ Positive samples } & \multicolumn{4}{|c|}{ cfu/gm } \\
\cline { 3 - 7 } & No. & $\mathbf{\%}$ & Min. & Max. & Mean \pm SE \\
\hline \hline Infested sample & 40 & 40 & 100 & $1.01 \times 10^{5}$ & $1.64 \times 10^{7}$ & $\begin{array}{c}2.21 \times 10^{6} \pm \\
6.30 \times 10^{5 *}\end{array}$ \\
\cline { 2 - 7 } $\begin{array}{c}\text { Non infested } \\
\text { samples }\end{array}$ & 30 & 30 & 100 & $1.8 \times 10^{4}$ & $2.03 \times 10^{6}$ & $\begin{array}{r}7.41 \times 10^{5} \pm \\
1.36 \times 10^{5}\end{array}$ \\
\hline
\end{tabular}

* Significant difference

Table (2): Frequency distribution of the examined meat samples based on their total aerobic count.

\begin{tabular}{||c||c|c||c|c||}
\hline \multirow{2}{*}{ Classes cfu/g } & \multicolumn{2}{c|}{ Sarcocysts infested samples } & \multicolumn{2}{c||}{ Normal samples } \\
\cline { 2 - 5 } & Frequency & $\%$ & 0 & $\%$ \\
\hline \hline$<10^{4}$ & 0 & 0 & 18 & 0 \\
$10^{4}-<10^{5}$ & 2 & 5 & 10 & 60 \\
$10^{5}-<10^{6}$ & 16 & 40 & 2 & 33.33 \\
$10^{6}-<10^{7}$ & 22 & 55 & 0 & 6.67 \\
$10^{7}-<10^{8}$ & 2 & 5 & 30 & 0 \\
\hline \hline Total & 40 & 100 & & 100 \\
\hline
\end{tabular}

Kafrelsheikh Vet. Med. J. Vol. 7 No. 1 (2009) 
Quality Of Buffaloe's Meat Infested With Sarcocystis.

Table (3): Statistical analytical results of total enterobacteriaceae count (cfu/g) of examined meat samples.

\begin{tabular}{|c|c|c|c|c|c|c|}
\hline \multirow{2}{*}{ Samples } & \multirow{2}{*}{$\begin{array}{l}\text { No. of examined } \\
\text { samples }\end{array}$} & \multicolumn{2}{|c|}{ Positive samples } & \multicolumn{3}{|c|}{ Count/g } \\
\hline & & No. & $\%$ & Min. & Max. & Mean $\pm \mathrm{SE}$ \\
\hline $\begin{array}{l}\text { Samples infested } \\
\text { with Sarcocysts }\end{array}$ & 40 & 39 & 97.5 & $1.2 \times 10^{4}$ & $9.7 \times 10^{5}$ & $\begin{array}{c}2.50 \times 10^{5} \pm \\
4.3 \times 10^{4}\end{array}$ \\
\hline $\begin{array}{c}\text { Non infested } \\
\text { samples }\end{array}$ & 30 & 18 & $60 \%$ & $1 \times 10^{3}$ & $3.1 \times 10^{5}$ & $\begin{array}{c}1.15 \times 10^{5} \pm \\
1.62 \times 10^{4}\end{array}$ \\
\hline
\end{tabular}

Table (4): Frequency distribution of the examined meat samples based on their total enterobacteriaceae count.

\begin{tabular}{||c||c|c||c|c||}
\hline \multirow{2}{*}{ Classes cfu/g } & \multicolumn{2}{|c|}{ Sarcocysts infested samples } & \multicolumn{2}{c|}{ Normal samples } \\
\cline { 2 - 5 } & Frequency & \% & Frequency & \% \\
\hline \hline$<10^{4}$ & 0 & 0 & 14 & 46.67 \\
$10^{4}-<10^{5}$ & 7 & 17.5 & 12 & 40 \\
$10^{5}-<10^{6}$ & 33 & 85.5 & 4 & 13.33 \\
\hline \hline Total & $\mathbf{4 0}$ & $\mathbf{1 0 0}$ & $\mathbf{3 0}$ & $\mathbf{1 0 0}$ \\
\hline
\end{tabular}

Table (5): Statistical analytical results of Staphylococcus aureus count (cfu/g) of examined meat samples.

\begin{tabular}{||c||c||c|c||c|c|c||}
\hline \multirow{2}{*}{ Samples } & \multirow{2}{*}{$\begin{array}{c}\text { No. of examined } \\
\text { samples }\end{array}$} & \multicolumn{2}{|c|}{ Positive samples } & \multicolumn{3}{|c|}{ Count/g } \\
\cline { 3 - 7 } & No. & $\%$ & Min. & Max. & Mean \pm SE \\
\hline \hline $\begin{array}{c}\text { Samples infested } \\
\text { with Sarcocysts }\end{array}$ & 40 & 19 & 47.5 & $1 \times 10^{4}$ & $9.65 \times 10^{5}$ & $\begin{array}{c}9.82 \times 10^{4} \pm \\
3.1 \times 10^{4}\end{array}$ \\
\cline { 2 - 7 } $\begin{array}{c}\text { Non infested } \\
\text { samples }\end{array}$ & 30 & 11 & 36.6 & $1 \times 10^{4}$ & $7.1 \times 10^{5}$ & $\begin{array}{c}5.96 \times 10^{4} \pm \\
2.56 \times 10^{4}\end{array}$ \\
\hline
\end{tabular}

Table (6): Frequency distribution of the examined meat samples based on their Staphylococcus aureus count.

\begin{tabular}{|c||c|c||c|c||}
\hline \multirow{2}{*}{ Classes cfu/g } & \multicolumn{2}{|c|}{ Sarcocysts infested samples } & \multicolumn{2}{c||}{ Normal samples } \\
\cline { 2 - 5 } & Frequency & $\mathbf{\%}$ & Frequency & $\%$ \\
\hline \hline Negative & 21 & 52.5 & 19 & 63.33 \\
$10^{4}-<5 \times 10^{4}$ & 4 & 10 & 1 & 3.33 \\
$5 \times 10^{4}<10^{5}$ & 4 & 10 & 3 & 10 \\
$10^{5}-<5 \times 10^{5}$ & 9 & 22.5 & 6 & 20 \\
$5 \times 10^{5}-<10^{6}$ & 2 & 5 & 1 & 3.33 \\
\hline \hline Total & $\mathbf{4 0}$ & $\mathbf{1 0 0}$ & $\mathbf{3 0}$ & $\mathbf{1 0 0}$ \\
\hline
\end{tabular}

Kafrelsheikh Vet. Med. J. Vol. 7 No. 1 (2009) 
Table (7): Statistical analytical results of yeast and mould count (cfu/g) of examined meat samples.

\begin{tabular}{|c|c|c|c|c|c|c|}
\hline \multirow{2}{*}{ Samples } & \multirow{2}{*}{$\begin{array}{l}\text { No. of examined } \\
\text { samples }\end{array}$} & \multicolumn{2}{|c|}{ Positive samples } & \multicolumn{3}{|c|}{ Count/g } \\
\hline & & No. & $\%$ & Min. & Max. & Mean \pm SE \\
\hline $\begin{array}{l}\text { Samples infested } \\
\text { with Sarcocysts }\end{array}$ & 40 & 32 & 80 & $1.11 \times 10^{4}$ & $1.52 \times 10^{6}$ & $\begin{array}{c}3.12 \times 10^{5} \pm \\
5.75 \times 10^{4}\end{array}$ \\
\hline $\begin{array}{c}\text { Non infested } \\
\text { samples }\end{array}$ & 30 & 16 & 53.3 & $3 \times 10^{3}$ & $9.2 \times 10^{5}$ & $\begin{array}{c}2.09 \times 10^{5}+ \\
4.97 \times 10^{4}\end{array}$ \\
\hline
\end{tabular}

Table (8): Frequency distribution of the examined meat samples based on yeast and mould count.

\begin{tabular}{||c||c|c||c|c||}
\hline \multirow{2}{*}{ Classes cfu/g } & \multicolumn{2}{c|}{ Sarcocysts infested samples } & \multicolumn{2}{c||}{ Normal samples } \\
\cline { 2 - 5 } & Frequency & $\%$ & Frequency & $\%$ \\
\hline \hline Negative & 8 & 20 & 14 & 46.67 \\
103 & 0 & 0 & 0 & 0 \\
$10^{4}-<5 \times 10^{4}$ & 7 & 17.5 & 1 & 3.33 \\
$5 \times 10^{4}-<10^{5}$ & 2 & 5 & 1 & 3.33 \\
$10^{5}-<5 \times 10^{5}$ & 9 & 22.5 & 9 & 30 \\
$5 \times 10^{5}-<10^{6}$ & 12 & 30 & 5 & 16.67 \\
$10^{6}-<5 \times 10^{6}$ & 2 & 5 & 0 & 0 \\
\hline \hline Total & 40 & 100 & 30 & 100 \\
\hline
\end{tabular}

Table (9): Statistical analytical results of protein percent of examined meat samples.

\begin{tabular}{|c|c|c|c|c|}
\hline Samples & No. & Min. & Max. & Mean \pm S.E \\
\hline Sarcocysts infested sample & 40 & 13.21 & 17.84 & $16.22 \pm 0.132 * *$ \\
\hline Non infested samples & 30 & 16.99 & 18.02 & $17.97 \pm 0.0339$ \\
\hline
\end{tabular}

$* *$ = Highly significant difference

Table (10): Statistical analytical results of fat percent of examined meat samples.

\begin{tabular}{||c||c||c||c||c||}
\hline Samples & No. & Min. & Max. & Mean \pm S.E \\
\hline \hline Sarcocysts infested sample & 40 & 0.31 & 3.22 & $1.50 \pm 0.134^{* *}$ \\
\hline Non infested samples & 30 & 0.93 & 4.39 & $2.33 \pm 0.215$ \\
\hline
\end{tabular}

$* *$ = Highly significant difference

Kafrelsheikh Vet. Med. J. Vol. 7 No. 1 (2009) 
Quality Of Buffaloe's Meat Infested With Sarcocystis.

Table (11): Statistical analytical results of ash percent of examined meat samples.

\begin{tabular}{|c|c|c|c|c|}
\hline Samples & No. & Min. & Max. & Mean \pm S.E \\
\hline Sarcocysts infested sample & 40 & 1.15 & 1.72 & $1.53 \pm 0.017 * *$ \\
\hline Non infested samples & 30 & 0.99 & 1.23 & $1.17 \pm 0.0106$ \\
\hline
\end{tabular}

** = Highly significant difference

Table (12): Statistical analytical results of moisture percent examined meat samples.

\begin{tabular}{|c|c|c|c|c|}
\hline Samples & No. & Min. & Max. & Mean \pm S.E \\
\hline Sarcocysts infested sample & 40 & 78.13 & 84.39 & $81.62 \pm 0.23^{* *}$ \\
\hline Non infested samples & 30 & 75.99 & 81.59 & $77.91 \pm 0.297$ \\
\hline
\end{tabular}

** = Highly significant difference

Table (13): Statistical analytical results of $\mathrm{pH}$ value of examined meat sample.

\begin{tabular}{|c||c||c||c||c|}
\hline Samples & No. & Min. & Max. & Mean \pm S.E \\
\hline \hline Sarcocyst infested sample & 40 & 5.69 & 6.09 & $5.93 \pm 0.021^{* *}$ \\
\hline Non infested samples & 30 & 5.01 & 5.56 & $5.31 \pm 0.0191$ \\
\hline
\end{tabular}

** = Highly significant difference

\section{DISCUSSION}

\section{Bacteriological examination of meat samples:}

The results recorded in Table (1) revealed that total aerobic bacterial count in all examined meat samples infested with Sarcocysts (100\%) ranged from $1.01 \times 10^{5}$ to $1.64 \times 10^{7} \mathrm{cfu} / \mathrm{g}$ with a mean value of $2.21 \mathrm{x}$ $10^{6} \pm 6.30 \times 10^{5}$ while, the total aerobic bacterial count of non infested meat samples ranged from $1.8 \times 10^{4}$ to $2.03 \times 10^{6}$ with a mean value 7.41 $\times 10^{5} \pm 1.36 \times 10^{5}$. These results shown highly significant increase in the total aerobic bacterial count of meat samples infested with Sarcocysts which may due to the high stress resulting from parasitic infestation which lead to immune depression giving a chance for bacterial multiplication (Colle et al., 1989). 
Results achieved in Table (2) showed that $55 \%$ of meat samples infested with Sarcocysts contain bacteria ranged from $10^{6}-<10^{7}$ while only $0 \%$ of non infested samples have this number. This result may show a direct relation between parasitic infestation and bacterial load as meat infested with parasites have a great probability of higher bacterial contamination (FAO, 1986).

The result recorded in Table (3) revealed that $97.5 \%$ of samples infested with Sarcocysts were contaminated by enterobacteriaceae, while only $60 \%$ of non infested samples were contaminated by such bacteria, also, the infested samples were contaminated at a level ranged from $1.2 \mathrm{x}$ $10^{4}$ to $9.7 \times 10^{5}$ with a mean value $2.50 \times 10^{5} \pm 4.3 \times 10^{4}$ while, the non infested sample showed a significant lower level of contamination ranged from $1 \times 10^{3}$ to $3.1 \times 10^{5}$ with a mean value of $1.15 \times 10^{5} \pm 1.62 \times$ $10^{4}$, while Table (4) showed that $85.5 \%$ of infested meat samples have Enterobacteriaceae at a level of $10^{5}-<10^{6}$ while only $13.33 \%$ of normal samples have the same frequency. Such result clearly showed the significant increased level of enterobacteriaceae bacteria (count and percent) in infested samples comparing with the nnon-infested ones this may attributed to the health disturbance and the immune suppression resulting from parasitism flourishing the multiplication of such bacteria which commonly inhabit the intestine of animals and may facilitate its migration from intestine to various body tissues (Duby et al., 1982).

From the results obtained in Table (5) it in evident that the Staphyloccus aureus were present in $47.5 \%$ of meat samples infested Sarcocysts and its number ranged from $1 \times 10^{4}$ to $9.65 \times 10^{5} \mathrm{cfu} / \mathrm{g}$ with a mean vale $9.82 \times 10^{4} \pm 3.1 \times 10^{4} \mathrm{cfu} / \mathrm{g}$. While, the Staphyloccous aureus count of non infested samples present in $36.6 \%$ and ranged from $1 \times 10^{4}$ to $7.1 \times 10^{5} \mathrm{cfu} / \mathrm{g}$ with a mean value of $5.96 \times 10^{4} \pm 2.56 \times 10^{4} \mathrm{cfu} / \mathrm{g}$. 
The highest frequency distribution of meat infested with Sarcocysts was $(22.5 \%)$ while, in non infested meat samples was (20\%) ranged from $10^{5}-<5 \times 10^{5} \mathrm{cfu} / \mathrm{g}$ as shown in Table (6).

These results showed non significant increase in the Staphylococcus aureus count in infested meat samples and this may be attributed to the fact that presence of Staphylococcus aureus is mainly from contamination of carcasses during slaughter and preparation either from animal or human sources $(\boldsymbol{I C M S F}, 1978)$ as the percent and level of contamination with staphylococci are most commonly related to be hygienic standards adopted during dressing and preparation of food animals carcasses (FAO, 1986).

From results recorded in Table (7) revealed that total yeast and mould count of examined meat samples infested with Sarcocysts (80\%) ranged from $1.11 \times 10^{4}$ to $1.52 \times 10^{6}$ with a mean value of $3.12 \times 10^{5}$ $\pm 5.75 \times 10^{4}$ while non infested samples which has total yeast and mould count $(53.3 \%)$ ranged from $3 \times 10^{3}$ to $9.2 \times 10^{5}$ with a mean value $2.09 \times$ $10^{5} \pm 4.97 \times 10^{4}$. While, Table (8) revealed that the highest frequency distribution meat samples infested with Sarcocysts (30\%) ranged from $\left(5 \times 10^{5}-<10^{6}\right)$ while, in non infested meat samples was $(16.67 \%)$ ranged from $\left(5 \times 10^{5}-<10^{6}\right) \mathrm{cfu} / \mathrm{g}$.

The non significant increase in the total yeast and mould in infested meat may be attributed to the fact that the level of carcasses contamination with mould and yeasts depends mainly on the level of environmental pollution with the fungal spores (Mizakova et al., 2002) as the hygienic standards applied during slaughtering have the superior role in controlling the level of mould, yeast contamination (FAO 1986). 
From results recorded in (Table 9) revealed reduction in the total protein percent in meat samples infested with Sarcocysts ranged from 13.21 to 17.84 with a mean value $16.22 \pm 0.132$ in comparison with non infested meat samples which has protein percent ranged from 16.99 to 18.02 with a mean of $17.97 \pm 0.0339$ the protein percent in infested samples was lower than non infested samples which may attributed to the adverse effect of such parasite on muscles constituents resulting from oedema and mayositis which lower muscle protein (Alan and Mac, 1996).

From results recorded in (Table 10) revealed that total fat percent of meat samples infested with Sarcocysts ranged from 0.31 to 3.22 with mean value $1.50 \pm 0.134$ while, in non infested ones the total fat percent ranged from 0.93 to 4.39 with a mean value $2.33 \pm 0.215$ so the fat percents were significantly lower in infested samples than non infested one. The results may be attributed to weakness and loss of appetite of animals resulting from infestation leading to excessive utilization of body fat (Dubey et al., 1982).

From results recorded in Table (11) revealed that the total ash percent of meat samples infested with Sarcocysts ranged from 1.15 to 1.72 with mean value $1.53 \pm 0.017$ while, in non infested ones the total ash percent ranged from 0.99 to 1.23 with a mean value $1.17 \pm 0.0106$ so the ash percent was higher in infested samples than non infested samples. This may attributed to the relative decrease in the dry matters (protein, fat) in infested meat samples as a result of lipolysis and protolysis and consequently increase in the inorganic matter concentration which are the main components of ash (Awad and Georgy, 1984). 
From results recorded in Table (12) revealed that the total moisture percent of meat samples infested with Sarcocysts ranged from 78.13 to 84.39 with mean value $81.62 \pm 0.23$ while in non infested ones the total moisture percent ranged from 75.99 to 81.59 with mean value $77.91 \pm$ 0.297 , so, the moisture percents were significantly higher in infested samples than non infested samples which may be attributed to excessive loss of fat and protein and accumulation of fluids (oedema) resulting from infestation.

\section{Determination of $\mathbf{p H}$ :}

From the results which recorded in Table (13) revealed that the ph value of meat samples infested with Sarcocysts ranged from $5.69 \pm 0.02$ in comparison with non infested samples which have $\mathrm{pH}$ value ranged from 5.01 to 5.56 with a mean value $5.31 \pm 0.0191$.

These results indicates highly significant increase of $\mathrm{pH}$ value of infested meat samples, this may attributed to the adverse effect of the parasite on biological activity of muscle retardation which retard muscle contraction and hardening, so decrease the ability to produce lactic acid by glycolysis and in complete muscle acidity (in complete rigor mortis) also the increase of $\mathrm{pH}$ value in infested meat may be due to its high moisture content (Robert et al., 1991).

\section{REFERENCES}

- Alan, B. and Mac, J. (1996). Poultry meat hygiene and inspection. Ministry of Agriculture, Fisheries and Food. London, UK.

- American Public Health Association “APHA" (1985). Standard methods for the examination of dairy products. $15^{\text {th }}$ Ed., G.H. Richardson, Washington, DC. 
- American Public Health Association “APHA” (1992). Compendium of methods for the microbiological examination also foods. $3^{\text {rd }} \mathrm{Ed}$. Washington, DC, USA.

- Association fo Official Analytical Chemists "AOAC” (1980). Official Methods of Analysis $13^{\text {th }} \mathrm{Ed}$, Washington, DC.

- Awad, Y.L. and Georgy, M.A. (1984). Some macro and micro elements in mutton meat under different health conditions. Egypt. J. Vet. Sci., 12(1): 57-64.

- Breaver, P.C., Gadgil, R.K. and Morera, P. (1979). Sarcocystis in man: a review and report of five cases. Am. J. Trop. Med. Hyg., 28: 819-844.

- Collee, J.C., Duguid, J.P.; Fraser, A.G. and Marmion, B.P. (1989). Practical Medical Microbiology. 13 ${ }^{\text {th }}$ Ed., Vol. 2 of Medical Microbiology. Churchill Living Stone Edinburgh London, Melbourne and New York.

- Dubey, J.P.; Spear, C.A. and Fayer, R. (1989). Sarcocystosis of animals and man. Boca Roton, Fla: IRC Pres. Inc., 1-215.

- Dubey, J.P.; Spear, C.A. and Shah, H.L. (1989). Ultra structure of Sarcocysts form water buffalo in India. Vet. Parasitol. 34: 149-152.

- Dubey, J.P.; Speer, C.A. and Epling, G.P. (1982). Sarcocystosis in newborn calves fed Sarcocystis cruzi sporcysts from coyotes. Am. J. Vet. Res.; 43: 2147-2164.

- Food and Agriculture Organization “FAO” (1986). Manuals of food control. Via delle Tremadicaracalla, 00100 Rome, Italy. 
- Hydorn, A.O.; Gestrich, R.; Mehlhorn, H. and Rommel, M. (1975).

Proposal for anew nomenlclature of sarcospiridia z. Parasitenki, 48: 73-82.

- International Commission on Microbiological Specification for Foods “ICMSF (1978). Microorganisms in food.2.Sampling for microbiological analysis Univ. Toronto, Toronto Press, Toronto, Canada.

- Mizakova, A.; Pipova, M. and Turek, P. (2002). The occurrence of moulds in fermented new meat products. Czech. J. Food Sci., 230: 89-94.

- Pearson (1984). Chemical Analysis of Food. $8^{\text {th }}$ Ed. Churchill Living Stone, Edinburgh, London.

- Railliet, A. and Lucet, A. (1891). Note sur quelque especes de coccidies encre peu etudies. Bull. Soc. Szool. Paris. 16: 246-250.

- Ranjhan, S.K and Pathak, N.N. (1983). Management and feeding of Buffaloes. Vikas libshing House PVT LTD. p. 21.

- Robert, K.; Peter, A.; Daryl, K. and Victor, W. (1991). Harper's biochemistry, $26^{\text {th }}$ Ed., Appleton and Lange, Norwalk, Connecticut, Los Altos, California, USA.

- Soulsby, E.J.L. (1986). Helminths, athropods and protozoa of domesticated animals seventh edition, English language Book Society. William Clowes Ltd. Beccles and London. 


\title{
جودة لجوم الجاموس المصابة بالساركوسيست
}

\section{نادر يحيى مصطفى يحيى و شربين عبل الفتاح ياسبين}

\author{
قسم مراقبة الأغذية ـ كلية الطب البيطري ـ جامعة كفر الثيخ \\ قسم الطفيليات - معهد بحوث صحة الحيوان
}

تعد لحوم الجاموس من أهم مصادر اللحوم فى مصر لاحتو ائها على العناصر الغذائية

الهامة و اللازمة لبناء جسم الإنسان وكمدر للبروتين الحيواني الضروري لحياة البشر . ولما كانت الجاموس من الحيو انات الأكثر عرضة للإصـابة بطفليات العضلات من نوع الساركوسيست التي تتسبب من كثثر من الخسار ات الاقتصادية المترتبة على إعدام الأجز اء المصابة من الحيوانات بهذه الطفيليات النى قد تنتقل إلى الإنسان وتضر بصحته. وحيث أن القوانين قد نصت بإعدام الأجزاء المصابة فقط و السماح للأجز اء التى لا تحمل الطفيل ليتم تتاولها فقد أجرينا هذه الدراسة لمعرفة مدى جودة هذه اللحوم الناتجة من حيوانات كانت مصابة بالطفيل بعد إعدام الأجزاء المصابة منها ومقارنتها باللحوم السليمة لمعرفة نأثير هذا الطفيل على جودة اللحوم من النواحي الميكروبيولوجية

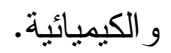

وقد جمع 70 عينة من الحم الجاموسي حيث شملت 40 عينة مصابة بالساركوسيست و 30 عينة غير مصابة لفحصها وتحليلها للتعرف على مدى التأثير الذي تسببه هذه الطفيليات على جودة

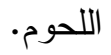


وقد أسفرت الدراسة على النتائج الآتية:

أولا: الفصص الميكروبيولوجى:

1 متوسط العدد الكلى للميكروبات الهوائية:

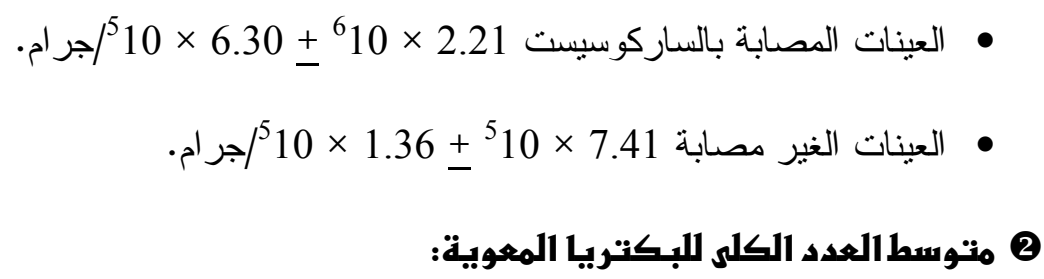

• العينات المصابة بالساركوسيست 2.5 ×

• العينات الغير مصابة 1.15 × 1.62 × 10 × 10 اجر ام.

3 متوسط العدد الكلى الميكروب العنقودى الذهبى:

• العينات المصابة بالساركوسيست 9.82 × 3.1 × 3.10 × 10 امر ام.

• العينات الغير مصابة 5.96 ×

4 (4) متوسطالعدد الكلى للفطريات والذمائر:

• العينات المصابة بالساركوسيست 3.12 × 5.75 × 10 × 10 اجر ام.

• العينات الغير مصابة 2.09 ×

ثانيا: التحليل الكيميائى:

10

• العينات المصابة بالساركوسيست 5.93 + 0.021.

• • العينات الغير مصابة 5.31 + 0.0191.

Kafrelsheikh Vet. Med. J. Vol. 7 No. 1 (2009) 


$$
\begin{aligned}
& \text { العينات المصابة بالساركوسيست } 16.22 \text { + 0.132. } \\
& \text { • العينات الغير مصابة } 17.97 \text { + 0.0339. }
\end{aligned}
$$

3 نسبة الدهون:

$$
\begin{aligned}
& \text { العينات المصابة بالساركوسيست } 1.5 \text { + } 0.134 . \\
& \text { • العينات الغير مصابة } 2.33 \text { + } 0.215 .
\end{aligned}
$$

\section{4 قياسر نسبة الرماد:}

$$
\begin{aligned}
& \text { العينات المصابة بالساركوسيست } 1.53 \text { + 0.017. } \\
& \text { • العينات الغير مصابة } 1.17 \text { + 0.0106. }
\end{aligned}
$$

5 قياسر نسبة الرطوبة:

$$
\begin{aligned}
& \text { • العينات المصابة بالساركوسيست } 81.62 \text { + } 0.23 . \\
& \text { • العينات الغير مصابة } 77.91 \text { + } 0.297 .
\end{aligned}
$$

هذا وقد دلت هذه النتائج على النأثثر السلبي لهذه الطفيليات العضلية على جودة اللحوم من زيادة لأعداد البكتريا الكلية وأعدا البكتريا المعوية ونقص نسبة البروتين و الدهن وارتقاع نسبة الرطوبة وارتقاع نسب درجة ايون الهيدروجين مقارنة باللحوم الغير المصابة والتي يستلزم معها التتدد فى فحص منل هذه اللحوم قبل السماح بتتاولها. أو اعتبارها نوعيات متدنية من اللحوم تستخدم في إنتاج المصنعات الأقل سعر ا بعد أخذ الاحتياطات اللازمة لحماية المستهلك و المحافظة على صحته. 